\title{
An Optimality Theory Account Of English Loanwords In Pilibhit Hindi-Urdu (Uttar Pradesh) India
}

\author{
Dedy Suhery, Mohd Hamid Raza, Happy Sri Rezeki Purba, Khairunnisah
}

\begin{abstract}
This paper contains the English Loanwords and their physical mechanism in Pilibhit Hind-Urdu that generalizes the different types of interchanging accounts of phonemes. The purpose of this paper is to present an account of English loanwords and their intervention in Urdu spoken in Pilibhit (U.P.), India within a framework of Optimality Theory (Prince and Smolensky, 1993). The groundwork of this study lead towards basically describe the facts and proposes theoretical account of alteration of phonemes in English Loanwords and how the native speakers of Pilibhit Hindi-Urdu substitute and break consonant cluster and use in communication. There are many conflicts in the intervention of phonemes as deletion, insertion, voicing, devoicing, assimilation, aspiration, deaspiration etc of English loanwords in Pilibhit Hindi-Urdu. We propose that such conflicts can be resolve by using Optimality Theoretic ranking of constraints and find out proper language specific facts expressed with parameters. This not only makes the grammar simpler, but it also allows the lower ranked constraints to have an effect in a non-conflict situation. This paper is about the nature of loanwords and more specially, the proper relationship between phonemes and candidate sets within the framework of Optimality Theory. We shall argue that the phonological information of phoneme is the best encoded in constraints rather than in representations. In this paper we examine some of the better-known arguments originally adduce in support of constraint rankings and argue that adoption of loanwords such a powerful mechanism and justified with proper evidence that create some effective processes at least in the cases discuses. Theoretical insights from OT enrich our understanding of Hindi-Urdu phonology, and data also reveal implicit figure prominently in the latest theoretical developments within OT.
\end{abstract}

Keywords: Optimality Theory, Loanwords, Consonant Clusters, Constraint Rankings.

\section{INTRODUCTION}

The District Pilibhit located in the sub-Himalayan belt on the boundary of Nepal and Uttarakhand and forms the part of the Rohilkhand division. It lies between the parallels of 28-6' and 28-53' north latitude and the meridians of 79-57' and $80-27$ 'east longitude. The district is spread over in an area of 3504 sq.km. In its general appearance, the district

Revised Manuscript Received on April 19, 2019.

Dedy Suhery, Department of English education, IAIN Langsa, Aceh Indonesia

Mohd Hamid Raza, Department of Linguistics of Aligarh Muslim University, Aligarh (U.P.), India

Happy Sri Rezeki Purba, Department of English Education, Muhammadiyah University of South Tapanuli, North Sumatra

Khairunnisah, Department of English Education, Muhammadiyah University of South Tapanuli, North sumatra presents diverse features and topographically be divided into several tracts.

Hindi and Urdu are generally considered two varieties of the same language, which is continually called Hindustani. Nevertheless, these two languages are strongly separated by different opinions in a state of disagreement, despite the fact their grammar, syntax and most of the basic vocabulary is identical. According to S.K. Chatterji (1890-1977), if there had not been such a type of settlement to the recognition of languages for serious literary purposes then it will be difficult to the development of these languages. Mahmood Khan Shirani (1880-1946) stated a hypothesis that Urdu is derived from Punjabi. It is hypothesized that Urdu is most influenced by Khari Boli, Haryanvi and Braj Bhasha that are regional dialects of Western Hindi in Uttar Pradesh, India. The objectives of this paper are to know the exact economic conditions of syllable structures in the words after the addition or elision of segments in the Urdu language.

Many linguists pointing the distinction in diverging vocabulary on formal levels. Pilibhit Hindi-Urdu is spoken extensively in documentation processes. It can be seen from a prolong language contact situation among different communities and having a way to switch linguistic features from each other especially loanwords. Pilibhit Hindi-Urdu is surrounded by many other languages and its varieties that have proper contact and interchange the peculiarity of loanwords. English is the most influential language that affected the other languages that are spoken in Pilibhit Native speakers of Pilibhit Hindi-Urdu borrowed the English words and used in its language with proper modification. They have a procedure of loanword adaptation such as addition, deletion, insertion, gemination etc. in English loanwords then used in native language. Pilibhit Hindi-Urdu speakers changed the physical mechanism of English loanwords and transformed into a different syllabic structure. Pilibhit Hindi-Urdu shares the same language family that is Indo-Aryan Language Family one of the significant sub-branch of Indo- Iranian a branch of IndoEuropean Language Family but have a distinction between them. 
International Conference on Recents Advancements in Engineering and Technology (ICRAET-18) |15th and 16th March 2019|Siddhartha Institute of Technology \& Sciences, Telangana, India.

\section{LITERATURE REVIEW}

\subsection{Consonant Clusters}

Nordquist (2017) stated that, in linguistics, a consonant cluster (CC) is a group of two or more consonant sounds that come before (called an onset), after (called a coda) or between (called medial) vowels. It can be considered in easy to understand that consonant cluster is a sequence of consonants in a specific group that occurs naturally in written and spoken languages - though sometimes may be altered phonetically. The written English language contains up to 46 permissible two-item initial consonant clusters, ranging from the common "st" to the less common "sq," but only 9 permissible three-item consonant clusters, as Michael Pearce (2001) posts in his book "The Routledge Dictionary of English Language Studies."

In the property of codas, or consonant clusters that occurs at the end of the words, they may comprise four segments that are often happened in rapid speech if the consonant cluster is too long, as in the word "glimpst" being acceptably written as "glimst." It is notified that the consonant cluster is very weak in Pilibhit Hindi-Urdu because they insert a vowel between or among the consonants and break the chain of consonants. Loan words adaptation patterns are perceived at the syllable level too. In English phonology the segments $/ \mathrm{m} /, / \mathrm{n} /, / \mathrm{l} / \mathrm{r} / \mathrm{functions}$ as the nucleus or syllabic consonants. But in Pilibhit Hindi-Urdu these consonants cannot act as syllabic consonants which lead to the emergence of epenthetic vowels in order to conform to the syllable structure of Phonology. For example, in Pilibhit Hind-Urdu we can observe that there is no arrangement of consonants of English loanwords such as;

\begin{tabular}{|c|c|}
\hline $\begin{array}{r}\text { English } \\
/ \text { terbl }\end{array}$ & $\begin{array}{l}\text { Pilibhit Hindi-Urdu } \\
\text { [tebəl] }\end{array}$ \\
\hline botl & botəl] \\
\hline /pædl/ & [paidəl] \\
\hline$/ \mathrm{t} \int æ n l$ & [t tenel] \\
\hline /sku:l/ & [isku:1] \\
\hline
\end{tabular}

Gloss
'table'
'bottle'
'paddle'
'channel'
'school'

Explanation through OT:

\begin{tabular}{|l|c|l|l|l|}
\hline /terbl & $\begin{array}{c}\text { *PEAK } \\
\text { (CONS) }\end{array}$ & $\begin{array}{l}\text { DEP- } \\
\text { IO }\end{array}$ & $\begin{array}{l}\text { ALIGN } \\
\text {-R }\end{array}$ & $\begin{array}{l}\text { CONTI } \\
\text { GUITY }\end{array}$ \\
\hline a. [terbl] & $* !$ & & & \\
\hline b. $\square$ [te.bəl] & & $* !$ & & $*$ \\
\hline c. [te.blu] & & $* !$ & $*$ & $*$ \\
\hline
\end{tabular}

Table :1 The Phonological representations of constraint rankings in Pilibhit Hindi-Urdu

Here the constraint *PEAK (CONS) is the fatal violation that created hurdles for candidate (a) to become an optimal candidate. In the tableau candidate (c) has violation and fatal violation both that are relevant to the higher rank of constraints. We can see that candidate (b) has least violation and rank of constraints, so he is the optimal candidate in this context and indicated by $\square$. Here we have rank of constraints as; $*$ PEAK(CONS) $>>$ DEP-IO $>>$ ALIGN$\mathrm{R}>>$ CONTIGUITY.

\subsection{Loanwords}

Borrowing is a term used in comparative and historical linguistics to refer to linguistic forms being taken over by one language or dialect from another; such "borrowings" are usually known as loanwords (Crystal, 1985:36). Linguistic borrowing is a theoretical framework of loanwords that are adopted or adapted from other languages and used them in its own language. Most of the languages adopted words without modification from other languages, but some have with the modification such as Pilibhit Hindi-Urdu. In addition, Kemmer (2004:1) states, "Loanwords are words adopted by the speakers of one language from a different language (the source language). From the definition above, the case study which relates to the main points is the loanwords occurred in English into Pilibhit Hindi-Urdu.

\subsection{Optimality Theory and its role in the description of syllables}

OT is a significant tool of Phonology and other branches of Linguistics that is recently used by many scholars to solve the problems of the syllabic structure of words. OT was first introduced by Prince and Smolensky (1993) for describing the syllable structure of words in a particular language, but soon it spread in other areas of Linguistics because its wide application became very effective at least in all fields of Linguistics. According to Gussenhoven and Haikes (1998), Optimality theory is thought as a universal set of constraints which are hieratically ranked on a language-specific basis. The relation between input and output is accounted for by respectively generating for each input all possible outputs and evaluating these outputs so as to select the optimal one.

Further, Alan Prince and Paul Smolensky (1993) introduced that $\mathrm{CON}$ tells us what the substantive constraints are, from which grammars are built. It investigates the Con is not a grammar of any language, but is a landmark of constraint rankings that identified the linguistic features of input and output candidates.

Related to definitions above, Optimality Theory (OT) has originally been developed for dealing with phonological problems, abandoning the assumption that grammatical constraints are inviolable (Prince \& Smolensky 1993/2004, McCarthy \& Prince 1995). Optimality Theory is not confined with the governing position of a particular candidate in Phonology, but it is also dealt with the fundamental new ideas have then soon been adopted in other grammatical domains, too, in syntax from Keating (1983), Ohala (1976) and Ball (2010).

\begin{tabular}{|c|c|c|l|}
\hline /input/ & Constraint 1 & Constraint 2 & Constraint 3 \\
\hline a.Candidate 'a' & $* !$ & $*$ & $*$ \\
\hline b.Candidate 'b' & & $* !$ & \\
\hline c पCandidate 'c' & & & $*$ \\
\hline
\end{tabular}

Table: 2 The Consideration of constraints and candidates with the reference of input 
In the above Table: 2 , we can observe that candidate ' $a$ ' has highest rank of constraints with the representation of violation as well as fatal violation, so he cannot be an optimal candidate. In the second, candidate ' $b$ ' has higher rank of constraint that is related to the fatal violation, so as the same procedure he cannot be an optimal candidate. Now we have last candidate ' $c$ ' that has least number of constraint rankings and related to the lowest violation as compare to the other candidates, so in this context candidate ' $c$ ' is the winner and known as 'optimal candidate'. Optimal candidate is strongly approached and has most of the linguistic features similar to the input candidate. Asterisk (*) is the notation of 'violation, Asterisk with the exclamation symbol (*!) represented 'fatal violation' and finger ( $\square$ ) notated the 'optimal candidate'.

\section{METHODS}

Two methods have been considered for data collection, namely actual field observation and documentary method.

\subsection{Actual Field Observation}

Blaike (1981: 12-18) reveals that the sources of data used in cross-language research needs the natural settings. Therefore, , the researchers have selected a list of English loanwords for the concentration of phonological processes that interchange the physical mechanism of tokens in Pilibhit Hindi-Urdu. It was large enough to yield significant results and contained high-quality samples. All the words are borrowed from the English language in the context of the language contact situation and sometimes refereed towards language teaching and learning process. The researchers use high quality of tools for the recording of data from the native speakers of the Pilibhit Hindi-Urdu. They have collected data through the interview. The subject's responses were tape recorded with an external instrument suspended from the speaker's neck, approximately 5 inches from the mouth. The selection was based on the following criteria.

1. A sufficient number of words to obtain reliable data.

2. High-frequency words (words should be comprehensible to most Pilibhit Hindi-Urdu speakers).

\subsection{Documentary Method}

The researchers collected primary data from the Pilibhit Hindi-Urdu native speakers within a period of one month that has widely used English loanwords at the time of the language contact situation. The researchers observed to the speakers had used the English loanwords continuously within the alterations of various segments and then he created an idea for the collection of original data. The researchers got continuously contact with native speakers and visit many times for the collection of fresh data. After the collection of data, the researchers transcribed it into phonemic transcription and find out the phonological process that has given the overview of segment properties. After that, the researchers applied the Optimality Theory to find out the basic syllable structure of loanwords in Pilibhit Hindi-Urdu.

\section{FINDINGS AND DISCUSSION}

Having analyzed the data collection found, there are some accounts involved in English loanwords of Philibit Hindi Urdu speakers .

\subsection{The Process of 'Epenthesis'}

Prothesis (from Greek pro- 'before' + thesis 'placing') is a kind of epenthesis in which a sound is inserted at the beginning of a word (Campbell, 1998, p. 31). He has standardized austere phenomena of segment insertion in the covenant condition that is not a specific frequent term, and such changes are also referred to as word-initial epentheses. The prepending of a vowel phoneme is called vocalic prothesis and the prepending of the consonantal phoneme is called prosthetic consonant in use. For example, in Pilibhit Hindi-Urdu, there is the addition of a front short close unrounded vowel [I] at the beginning of English loanwords such as;

$\begin{array}{ccc}\text { English } & \text { Pilibhit Hindi-Urdu loanwords } & \text { Gloss } \\ \text { /sku:l/ } & \text { [Isku:l] } & \text { 'school } \\ \text { /sprart/ } & \text { [Isprrart] } & \text { 'sprite' } \\ / \text { sprf(ə)l/ } & \text { [ispesəl] } & \text { 'special' } \\ / \text { steIJ(ə)n/ } & \text { [Istesən] } & \\ \text { 'station' } & & \end{array}$

/spi:d/ [ispi:t]

'speed'

Applications of Optimality Theory in /sku:l

\begin{tabular}{|l|c|c|c|r|}
\hline \multicolumn{1}{|c|}{ /sku:l } & $\begin{array}{c}* \text { COMP-O } \\
\text { NS }\end{array}$ & DEP-IO & $*$ CODA & $\begin{array}{r}\text { CONTI } \\
\text { GUITY }\end{array}$ \\
\hline a. [sku:l] & $* !$ & & $*$ & \\
\hline b. [ [1s.ku:l] & & $* !$ & $* *$ & \\
\hline $\begin{array}{l}\text { c. } \\
\text { [st.ku:l] }\end{array}$ & & $* !$ & $*$ & $*$ \\
\hline
\end{tabular}

Table: 3 The Representation of consonant cluster between [s] and [k] in Pilibhit Hindi-Urdu loanwords derived from English.

*COMP-ONS >> DEP-IO >> *CODA >>CONTIGUITY

Consideration of Optimality Theory in /sprst/

\begin{tabular}{|c|c|c|c|c|}
\hline /spr^It/ & $\begin{array}{l}\text { *COMP- } \\
\text { ONS }\end{array}$ & $\begin{array}{l}\text { DEP- } \\
\text { IO }\end{array}$ & $\begin{array}{l}{ }^{* \mathrm{COD}} \\
\mathrm{A}\end{array}$ & $\begin{array}{l}\text { CONTIGU } \\
\text { ITY }\end{array}$ \\
\hline a. [spr $\wedge \mathrm{rt}]$ & $* !$ & & * & \\
\hline $\begin{array}{l}\text { b. } \\
\text { [Is.pira.It] }\end{array}$ & & $* !$ & $* * *$ & $*$ \\
\hline $\begin{array}{l}\text { c. } \\
\text { [is.pra.rt] }\end{array}$ & $* !$ & * & $* *$ & \\
\hline
\end{tabular}

Table: 4 The Representation of consonant cluster among [s], [p] and [r] in Pilibhit Hindi-Urdu loanwords derived from English.

*COMP-ONS $>>$ DEP-IO $>>$ *CODA $>>$ CONTIGUITY 
International Conference on Recents Advancements in Engineering and Technology (ICRAET-18) |15th and 16th March 2019|Siddhartha Institute of Technology \& Sciences, Telangana, India.

Consideration of Optimality Theory in /ster $/(\theta) \mathrm{n} /$ :

\begin{tabular}{|c|c|c|c|c|}
\hline$/$ ster $\int(\partial) n /$ & $\begin{array}{l}{ }^{*} \mathrm{COM} \\
\mathrm{P}-\mathrm{ONS}\end{array}$ & DEP-IO & * CODA & $\begin{array}{l}\text { MAX- } \\
\text { IO }\end{array}$ \\
\hline $\begin{array}{l}\text { a. } \\
{\left[\text { ster. } \int(ə)\right.} \\
\text { n] }\end{array}$ & $* !$ & & $*$ & \\
\hline $\begin{array}{l}\text { b. } \\
\text { [Is.te.sən] }\end{array}$ & & $* !$ & ** & * \\
\hline $\begin{array}{l}\text { c. } \\
\text { [ste.sən] }\end{array}$ & $* !$ & & $*$ & $*$ \\
\hline
\end{tabular}

Table: 5 The representation of consonant cluster between $[s]$ and $[t]$ in Pilibhit Hindi-Urdu derived from English.

In the analysis of 'prothesis', we have seen that how a Pilibhit Hindi-Urdu speakers added a segment in the initial position of English loanwords and break the consonant cluster between [s] and [k]. In Table 4, we have analyzed English loanword /sku:1/ 'school' to [Is.ku:1], earlier addition to the front short close unrounded vowel [I]. It was the monosyllabic word, but after adding it became the disyllabic word. In the case of constraint rankings we have generalized that candidate ' $a$ ' has the highest rank of constraints with the violation and fatal violation and there is the least similarity between input and output candidate. We have analyzed that candidate ' $b$ ' has the least rank of constraints and having the most similarity of linguistic features with input candidate, so he is the winner and became 'optimal' candidate and indicated by $\square$. In the account of candidate ' $c$ ', he has a higher rank of constraints and lost the opportunity to be the optimal candidate regarding a lack of linguistic features with input candidate. There is a hierarchy of constraint rankings that began from the highest rank of constraints to the lowest rank of constraints has given below;

*COMP-ONS $>>$ DEP-IO $>$ > CODA $\gg$ CONTIGUITY

We have to explain the constraints as, *COMP-ONS is the highest rank of constraint that means there must not be more than one consonant at the onset position of the syllables, DEP-IO is the higher rank of constraint that means output candidate must be correspondent to input candidate, in general terms we can say that 'No Epenthesis, *CODA is the lower rank of constraint that means prohibition of coda consonant or support to the open syllable and CONTIGUITY is the lowest rank of constraint that means prohibition of insert an extra segment between two or more consonants.

In Table 4, we have analyzed another English loanword /sprs.It/ 'sprite' that has a sequence of three consonants at the onset position of a syllable changed into [Is.pira.It] in Pilibhit Hindi-Urdu. Constraints are the same as in Table 2, and the candidate ' $b$ ' is the optimal candidate notated by $\square$. In Table 5, we have analyzed how a disyllabic word became a trisyllabic word after the addition of some external segment. In the case of a candidate, ' $a$ ' has the highest rank of constraints regarding the violation and fatal violation of constraints. In the performance of candidate ' $b$ ' has the least number of constraint rankings and most of the linguistic features are matching with the input candidate, so in this context, he is the winner and declared as an optimal candidate. The optimal candidate is indicated by $\square$ in the table. There is a hierarchy of rank of constraints that began from the highest ranking constraints to lowest ranking constraints.

\section{*COMP-ONS $>>$ DEP-IO $>>*$ CODA $>>$ CONTIGUITY}

In Table 5, we have analyzed that a short front close unrounded vowel [I] is added at the beginning of the English loanword and break the consonant cluster between voiceless alveolar fricative [s] and voiceless alveolar stop [t]. One of the interesting points is that speakers altered the phonetic property of post-alveolar fricative [S] to [s] after the addition of an external segment. In the process of the candidate, ' $a$ ' has the highest rank of constraints within the disyllabic word and having the smallest number of linguistic features that are apart from the input candidate. In the aspect of candidate ' $b$ ' has the least rank of constraints and having most of the linguistic features that are approached to the input candidate and became the winner. The candidate ' $b$ ' is the most favourable and became the optimal candidate and indicated by $\square$. There is a hierarchy of constraints that began from the most rank of constraints to the least rank of constraints has given below;

\section{*COMP-ONS $>>$ DEP-IO $>>*$ CODA $>>$ MAX-IO}

The constraint MAX-IO is the lowest rank of constraint that means that the input candidate must be correspondent to output candidate. In general terms, we can say 'No Deletion'.

\subsection{The Process of Anaptyxis}

Anaptyxis (from Greek ana-ptusso 'unfold, open up, expand') is a kind of epenthesis in which an extra vowel is inserted between two consonants (also called a 'parasitic' vowel or 'svarabhakti' vowel) (Campbell, 1998, p. 33). It has often assumed that the epenthetic vowel in a particular language is a copy vowel, an unmarked vowel or a nonsalient default vowel; For example, Pilibhit Hindi-Urdu has a theoretical procedure of inserting a vowel between two other segments that broke the consonant cluster of English loanwords has given below such as;

\section{*COMP-ONS $>>$ DEP-IO $>>* C O D A>>M A X-I O$}

$\begin{array}{ccc}\text { English } & \text { Pilibhit Hindi-Urdu loanwords } & \text { Gloss } \\ / \mathrm{drop} / & \text { [drra:p] } & \text { 'drop } \\ / \mathrm{blok} / & \text { [brla:k] } & \text { 'block' } \\ / \mathrm{frlm} / & \text { [frləm] } & \text { 'film' } \\ / \mathrm{terb} / & \text { [tebrl] } & \text { 'table' } \\ / \mathrm{b} \Delta \mathrm{tm} / & \text { [bətən] } & \text { 'button' } \\ / \mathrm{pa}:(\mathrm{r}) \mathrm{k} / & \text { [pa:rək] } & \text { 'park' }\end{array}$

Explanation through OT: The delineation of consonant clusters between various types of segments and their linguistic features has given below in the tables;

Analysis of /terbl/an English loanword in Pilibhit HindiUrdu through constraint rankings: 


\begin{tabular}{|c|c|c|c|c|}
\hline$/$ terbl/ & $\begin{array}{l}* \mathrm{PEA} \\
\mathrm{K}-\mathrm{CO} \\
\mathrm{NS}\end{array}$ & $\begin{array}{l}\text { DEP-I } \\
0\end{array}$ & $\begin{array}{l}\text { ALIG } \\
\text { N-R }\end{array}$ & CONTIGUITY \\
\hline a. [terbl] & *! & & & \\
\hline b. Q [te.brl] & & $* !$ & & * \\
\hline $\begin{array}{l}\text { c. } \\
\text { [te.br.li] }\end{array}$ & & $* !$ & $*$ & * \\
\hline
\end{tabular}

Table: 6 The General speculative consonant clusters of English loanwords that separated two adjacent consonants by inserting a vowel into Pilibhit HindiUrdu.

$*$ PEAK-CONS $>>\quad$ DEP-IO $>>\quad$ ALIGN-R
$>$ CONTIGUITY

Analysis of /fılm/ an English loanword in Pilibhit HindiUrdu by implication of OT model:

\begin{tabular}{|l|l|l|l|c|}
\hline$/$ frlm/ & $\begin{array}{l}\text { *PEA } \\
\text { K-CO } \\
\text { NS }\end{array}$ & $\begin{array}{l}\text { ALIG } \\
\text { N-R }\end{array}$ & DEP-IO & CONTIGUITY \\
\hline $\begin{array}{l}\text { a. } \\
\text { [ftlm] }\end{array}$ & $* !$ & & & \\
\hline $\begin{array}{l}\text { b. } \\
\text { fr.lom } \\
]\end{array}$ & & & $* !$ & $*$ \\
\hline $\begin{array}{l}\text { c. } \\
\text { [frlmi } \\
]\end{array}$ & & $* !$ & $*$ & $*$ \\
\hline
\end{tabular}

Table: 7 The Executive phonological structure of /film/ in Pilibhit Hindi-Urdu that is borrowed from English in language contact situation.

*PEAK-CONS $>>$ ALIGN-R $>\quad$ EP-IO $>>$ *OMPLEXCOD

In the analysis of 'anaptyxis', we have seen that an external segment is inserted in the medial position of a word for creating a remoteness between two adjacent consonants in Pilibhit Hindi-Urdu.

In Table 6 candidate ' $a$ ' contained the syllabic consonant that occupied the position of the peak in a syllable but has the highest rank of constraints and did not correspond the linguistic features with input candidate. In the form of candidate ' $b$ ' has the least number of violations and more accepted by constraints, so the candidate ' $b$ ' became the winner candidate and represented as optimal candidate notated by $\square$. In the candidate ' $b$ ' there is inserted a short close mid unrounded vowel [I] at the end of the syllable between bilabial voiced stop [b] and alveolar voiced lateral [1] that break the consonant cluster. Candidate ' $c$ ' has a higher rank of constraints and more violations as compare to the candidate ' $b$ '. ALIGN-R means there must not be an addition at the right edge of the candidate. There is a sequence of constraint rankings that began from highest to lowest such as;

*PEAK-CONS $>>$ DEP-IO $>>$ ALIGN$\mathrm{R}>>$ CONTIGUITY $>>*$ COMPLEX-CODA
*COMPLEX-CODA means there must not be a consonant cluster at the coda position of a syllable in a particular word.

In Table 7, we have analyzed an English loanword /fılm/ in Pilibhit Hindi-Urdu by the insertion of schwa [ə] that separate the consonant cluster at the end of the word and became [filəm]. Candidate ' $a$ ' has a consonant cluster and syllabic consonant but relevant to the highest rank of constraints as a comparison to the other candidates. Candidate ' $b$ ' has the least rank of constraints that exceed the syllable and declared an optimal candidate marked by $\square$. We have organized a sequence of constraint rankings has given below;

*PEAK-CONS $>>$ ALIGN-R $>\quad$ EP-IO $>>*$ COMPLEX-
COD

\subsection{The Influence of Paragoge}

Paragoge (from Greek paragoge 'a leading past') adds a sound (usually a vowel) to the end of a word (Campbell, 1998 , p. 35). It generally happens in the rapid speech of a speaker who is not more aware of the act of articulation. Further, Paragoge is an account of word-final vowel epenthesis that robustly attested in all types of language contact, but vanishingly rare in "normal" L1 transmission. For example; in Pilibhit Hindi-Urdu, there is a common phenomenon of the addition of a short back close rounded

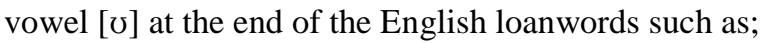

$\begin{array}{lc}\text { English } & \text { Pilibhit Hindi-Urdu } \\ / \mathrm{pl} \wedge / & \text { [prləku] } \\ / \mathrm{t} \wedge \mathrm{m} / & \text { [temu] } \\ / \mathrm{p} \wedge \mathrm{rp} / & \text { [pepu] } \\ / \text { gla:s/ } & \text { [grla:su] } \\ / \mathrm{m} \wedge \mathrm{rt}(\mathrm{r}) / & {[\text { mi:təru] }} \\ / \mathrm{n} \wedge \mathrm{mb}(\mathrm{r}) / & \text { [nəmbəru] }\end{array}$

Gloss
'plug'
'time'
'pipe'
'glass'
'miter'
'number'

Analysis of English loanword /plıg/ through Optimality theory:

\begin{tabular}{|c|c|c|c|c|}
\hline$/ \mathrm{pl} \mathrm{g} /$ & $\begin{array}{l}\text { *COMP- } \\
\text { ONS }\end{array}$ & $\begin{array}{l}\text { DEP- } \\
\text { IO }\end{array}$ & $\begin{array}{l}\text { ALIGN } \\
-R\end{array}$ & $\begin{array}{l}\text { *VOI-C } \\
\text { ODA }\end{array}$ \\
\hline a. $[\mathrm{pl} \wedge \mathrm{g}]$ & $* !$ & & & $*$ \\
\hline b. $\square[\mathrm{pr} . \mathrm{l} ə \mathrm{ku}]$ & & $* !$ & $*$ & \\
\hline c. [plı.ku] & $* !$ & $*$ & $*$ & \\
\hline
\end{tabular}

Table: 8 The Hierarchy of constraint rankings took place in specific position and thrust the subject of consonant cluster in different ways between the input and output candidate.

*COMP-ONS >> DEP-IO >> ALIGN-R >> *VOI-CODA

In this condition, we have applied eloquent angle to find out the exact direction of consonant clusters in English loanwords that are borrowed in Pilibhit Hindi-Urdu. Here we have given an

OT analysis of /gla:s/ an English loanword in Pilibhit Hindi-Urdu; 
International Conference on Recents Advancements in Engineering and Technology (ICRAET-18) |15th and 16th March 2019|Siddhartha Institute of Technology \& Sciences, Telangana, India.

\begin{tabular}{|l|c|c|c|c|}
\hline \multicolumn{1}{|c|}{ gla:s/ } & $\begin{array}{l}\text { *COMP } \\
\text {-ONS }\end{array}$ & DEP-IO & ALIGN-R & *AGR-VOI \\
\hline a. [gla:s] & $* !$ & & & $*$ \\
\hline $\begin{array}{l}\text { b. } \\
\text { [gr.la:su] }\end{array}$ & & $* !$ & $*$ & \\
\hline \begin{tabular}{l} 
c. [gla:su] \\
\hline
\end{tabular} & $* !$ & $*$ & $*$ & $*$ \\
\hline
\end{tabular}

Table: 9 The Characterization of agreement between two specific segments approach to identical features at the end of the words.

*COMP-ONS $>>$ DEP-IO >> ALIGN-R > $>$ *AGR-VOI

In the theoretical perspective of 'paragoge', we have seen that the Pilibhit Hindi-Urdu speakers added a short back close rounded vowel [u] at the end of the English loanwords. This is happening in the sense of rapid articulation of a particular word to ease of understanding. In Table 8, the Candidate ' $a$ ' has the highest rank of constraints and violated most of the linguistic features as compare to the input candidate. In the account of candidate ' $b$ ' has the least rank of constraints and most similar linguistic features with input candidate became winner candidate and declared the optimal candidate indicated by $\square$. Candidate 'c' has a higher rank of constraints as compare to the candidate ' $b$ ' and less similar linguistic features with input candidate. There is a hierarchy of constraints given below;

*COMP-ONS $>>$ DEP-IO $>>$ ALIGN-R $>$ > VOI-CODA

$*$ VOI-CODA is the lowest rank of constraint that means there must not be a voiced consonant at the coda position of a syllable. In Table 8 there is the same process as in Table 9.

\subsection{Regressive Assimilation}

Regressive assimilation appears when the final sound of the preceding word or syllable becomes similar to, or the same as, the initial sound of the following word or syllables (Djarjowidjojo, 2009). According to Pandey (2018), if the direction of assimilation is leftward, that is the preceding sound acquires the features of the following sound, the process is regressive or anticipatory assimilation. For example, Pilibhit Hindi-Urdu speakers changed the physical mechanism of preceding sound that became identical to the following sound in English loanwords such as;

\begin{tabular}{|c|c|c|}
\hline 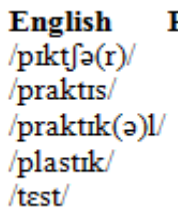 & $\begin{array}{l}\text { Pilibhit Hindi-Urdu loanwords } \\
\left.\text { [prtft } \int \partial r\right] \\
\text { [prrəttrs] } \\
\text { [prrattrkal] } \\
\text { [prlattrk] } \\
\text { [tett] }\end{array}$ & $\begin{array}{l}\text { Gloss } \\
\text { 'picture' } \\
\text { 'practice' } \\
\text { 'practical } \\
\text { 'plastic' } \\
\text { 'test' }\end{array}$ \\
\hline
\end{tabular}

Now consider towards the OT analysis of assimilation process of English loanwords:

\begin{tabular}{|l|c|c|c|l|}
\hline$/$ piktfə(r)/ & $\begin{array}{l}\text { IDEN } \\
\text { T-STR } \\
\text { D }\end{array}$ & $\begin{array}{l}\text { *DELA } \\
\text { Y-RLS }\end{array}$ & $\begin{array}{l}\text { AGRE } \\
\text { E-VOI }\end{array}$ & $*$ Cor-Ant \\
\hline $\begin{array}{l}\text { a. } \\
\text { [pik.tfə(r)] }\end{array}$ & $* !$ & $*$ & & $*$ \\
\hline $\begin{array}{l}\text { b. } \\
\text { [prtf.tfər] }\end{array}$ & & $* ! *$ & & $* *$ \\
\hline $\begin{array}{l}\text { c. } \\
\text { [prg.tfər] }\end{array}$ & & $* !$ & $*$ & $*$ \\
\hline
\end{tabular}

Table: 10 The Representation of two identical sounds with the function of constraint rankings.
IDENT-STRD>>*DELAY-RLS>>AGREEVOI $>$ *COR-ANT

Now consider about another candidate of English word that is adapted in Pilibhit Hindi-Urdu with full concentration by OT model:

\begin{tabular}{|l|l|l|l|l|}
\hline /plastrk/ & $\begin{array}{l}{ }^{*} \text { COM } \\
\text { P-ONS }\end{array}$ & $\begin{array}{l}\text { DEP-I } \\
\text { O }\end{array}$ & $\begin{array}{l}\text { AGREE } \\
\text {-VOI }\end{array}$ & $\begin{array}{l}\text { IDENT-OB } \\
\text { S }\end{array}$ \\
\hline $\begin{array}{l}\text { a. } \\
\text { [plas.trk] }\end{array}$ & $* !$ & & & $*$ \\
\hline $\begin{array}{l}\text { b. } \square \\
\text { [pilat.trk] }\end{array}$ & $* !$ & $* !$ & & \\
\hline $\begin{array}{l}\text { c. } \\
\text { [plad.trk] }\end{array}$ & $*$ & & $*$ & \\
\hline
\end{tabular}

Table: 11 The Phonological organizations of speech sounds with the systematic function of constraints that affected to the candidates in different ways.

*COMP-ONS $>$ DEP-IO $>>$ AGREE-VOI $>$ IDENTOBS

In Table 10, we have analyzed the process of 'regressive assimilation'. This is happening when both preceding as well as following sounds are obstruents. The velar voiceless stop [k] changed into affricate voiceless post-alveolar [t $\left.\int\right]$ when it is followed by a schwa [ə]. The Candidate ' $a$ ' has the highest rank of constraints and most of the violations relevant to the input candidate. Candidate ' $b$ ' has the least rank of constraints and most analogical features related to the input candidate as compared to others. So, he became the winner and marked as an optimal candidate, indicated by $\square$. The Candidate ' $\mathrm{c}$ ' have the higher ranks of constraints and more approach to the candidate ' $a$ '. There is a hierarchy of constraints that are applied for regressive assimilation has given below;

IDENT-STRD $>>* D E L A Y-R L S>>$

AGREEVOI $>*$ COR-ANT

IDENT-STRD is the highest rank of constraint that means two adjacent affricate sounds must be identical. *DELAYRLS is a higher rank of constraint that means there must not be a delay in the releasing of a consonant. AGREE-VOI is the lower rank of constraint that means there must concord in voicing within to approach segments.

*COR-ANT is the lowest rank of constraint that means there must not be stricture of front sounds.

\subsection{Devoicing at Coda Position}

When a consonant that is normally voiced is pronounced without vocal-fold vibration in some context, it is said to be devoiced (Gussenhoven \& Jacobs, 2017, p. 20). It is interesting to know that the voiced consonants are substituted with the voiceless consonants at the coda position of English loanwords in Pilibhit Hindi-Urdu. Devoicing is a phonological process that can occur in language or dialect with typical phonological development and at a very early age, usually under three. The researcher found several examples of one phonological process in the category of voicing alterations such as; 


\begin{tabular}{|c|c|}
\hline $\begin{array}{l}\text { English } \\
\text { /tju:b/ } \\
\text { ka:d/ } \\
\text { /bo:d/ } \\
\text { /raud/ } \\
\text { /plisg/ } \\
\text { /rod/ } \\
\text { /blerd/ } \\
\text { /sard/ }\end{array}$ & $\begin{array}{l}\text { Pilibhit Hindi-Urdu loanwords } \\
\text { [tu:p] } \\
\text { [ka:t] } \\
\text { [bo:t] } \\
\text { [ro:t] } \\
\text { [pilak] } \\
\text { [ra:t] } \\
\text { [ble:t] } \\
\text { [sətt] }\end{array}$ \\
\hline
\end{tabular}

An OT Analysis of / tju:b/an English loanword in Pilibhit Hindi-Urdu with systematic convention of constraint rankings:

\begin{tabular}{|l|l|l|l|l|}
\hline$/$ tju:b/ & $\begin{array}{l}* \text { VOI- } \\
\text { CODA }\end{array}$ & $\begin{array}{l}\text { MAX- } \\
\text { IO }\end{array}$ & $\begin{array}{l}\text { IDENT-I } \\
\text { O(VOI) }\end{array}$ & \\
\hline a. [tju:b] & $* !$ & & & $*$ \\
\hline b. $[$ [tu:p] & & $* !$ & $*$ & \\
\hline c. [tu:b] & $* !$ & & $*$ & $*$ \\
\hline d. [dju:b] & $* !$ & & $*$ & $* *$ \\
\hline e. [du:p] & & $* !$ & $* *$ & $*$ \\
\hline
\end{tabular}

Table: 12 The Phonological representations of devoicing of obstruent sound at the coda position. *VOI-CODA $>>$ MAX-IO >> IDENT-IO(VOI) >>VOP

The consideration of input candidate /ka:d/ in OT model:

\begin{tabular}{|l|c|l|l|l|}
\hline /ka:d/ & *VOI-CODA & $\begin{array}{l}\text { IDEN } \\
\text { T-IO( } \\
\text { VOI) }\end{array}$ & *SG & VOP \\
\hline a. [ka:d] & $* !$ & & & $*$ \\
\hline b. $[$ [ka:t] & & $* !$ & & \\
\hline $\begin{array}{l}\text { c. } \\
{[\mathrm{kha}: \mathrm{d}]}\end{array}$ & $* !$ & & $*$ & $*$ \\
\hline
\end{tabular}

Table: 13 The Phonological devoicing of obstruent segment at the end of a particular word.

*VOI-CODA > IDENT-IO(VOI)> $>$ *SG $>$ VOP

In Table 12, we have analyzed the 'coda devoicing' condition in Pilibhit Hindi-Urdu that adapted coda voiced from English loanwords. The voiced sound became voiceless sound at the end of the words when it is preceded by tense vowels. The Candidate ' $a$ ' preserved the voicing feature of coda condition but, he has the highest rank of constraints and least analogous features as compare to the input candidate. On the other hand candidate, ' $b$ ' did not preserve the voicing of coda at the end of the word but, he has the least rank of constraints as compared to other output candidates and became the winner or optimal candidate denoted by $\square$. Other candidates as ' $c$ ', ' $\mathrm{d}$ ' and 'e' has a higher rank of constraints and did not preserve the linguistic features of the input candidate, so they became loser candidates. There is a row of constraint rankings that began from highest to lowest rank of constraints;

\section{*VOI-CODA $>>$ MAX-IO $>>$ IDENT-IO VOI) $>>$ VOP}

Here MAX-IO is the higher rank of constraint just after the first constraint that means the input candidate must correspondent to output candidate. IDENT-IO (VOI) is a lower rank of constraint that means there must be identical voicing between the segments of input and output candidates. VOP is the lowest rank of constraint that means obstruents must be voiceless. In Table 13, we have analyzed the same process of devoicing that is happened in Table 12.

\section{CONCLUSION}

In this study, we have investigated the occurrence of phonological processes with the implication of Optimality Theory. We have explored how a Pilibhit Hindi-Urdu speaker broke the consonant cluster with the addition or insertion of a particular vowel in the English loanwords. It is investigated that Pilibhit Hindi-Urdu speakers did not preserve the consonant clusters in the initial, medial and final position of English loanwords. It is found that Pilibhit Hindi-Urdu speakers have the assimilation process between the two obstruent segments. We have tried to find out the facts that there is coda devoicing in the monosyllabic words when it is preceded by a tense vowel.

In the syllabification pattern, we have taken the advantage of a constraint-based approach like OT that captures certain generalizations that are missed in a generative rule-based approach. The analysis proposed in this paper employs markedness constraints and faithfulness constraints. We have applied various types of the rank of constraints with the help of Optimality Theory and find out the optimal candidate. This study carried out the phonological framework of Pilibhit Hindi-Urdu with the auspicious vantage towards the hierarchy of constraint rankings. It is considered that OT constraints do compare all members of the output candidates with input candidate and turns out to be remarkably straightforward and efficient to determine a workable ranking from a set of pair wise-comparisons, and to determine an optimal candidate.

\section{ACKNOWLEDGMENTS}

We would like to thank all participants for their participation in this research work who supported our work done completely and helped us to get results of better quality. We are also very grateful to the informants for their patience and support in overcoming numerous obstacles during the data collection.

\section{REFERENCES}

1. Shirani, M.K. "Punjan men Urdu”. Lucknow: Nasim Book Depot, 1870.,pp.20-45.

2. Chatterji, S.K. "The Origin and Development of the Bengali Language". Vol, I and II, London: George Allen \& United Lid, 1970,pp. 80-95.

3. Blaikie, Norman. (2000). Designing Social Research:The Logic of anticipation. Polity Press,2000, pp.12-18. 
4. Nordquist, R, Cited in Tought Co. as learn about consonant clusters in English Grammar,2017, pp.50-55.

5. Pearce, Michael , A Glossary of Historical Linguistics. Edinburgh: Edinburgh University Press, 2001,pp 134140.

6. Crystal, D, Linguistics. England: Penguin, 1985, pp 36.

7. Prince, A. \& Smolensky, P. (1993). Optimality Theory: Constraint Interaction in Generative Grammar. Rutgers University Center for Cognitive Science,1993, Technical Report 2

8. Achard, M. \& Kemmer, S. "Language, Culture and Mind", U.S.A.: Centre for the study language and Inf,2004, pp 105-110

9. Gussenhoven, C. \& Jacobs, H. "Understanding Phonology" (7 ed). Oxon: Routledge,2017, pp 75-85.

10. McCarthy, J. J. "A Thematic Guide to Optimality Theory". Cambridge: Cambridge University Press, 2002, pp 155-165.

11. Ohala, J. J. “A Model of Speech Aerodynamics”. Report of the Phonology Laboratory (Berkeley) 1, 1976, pp 93 107.

12. Prince, A. \& Smolensky, P.”. Optimality Theory: Constraint Interaction in Generative Grammar." Ms. Rutgers University, New Brunswick and the University of Colorado, Boulder. Later published as in 2004 from Blackwell Publishing, Malden, MA,1993.

13. Ball, H. Elston and S. Neuval (eds.) CLS 37: The main session. Papers from the 37th meeting of the Chicago Linguistic Society Chicago: The Chicago Linguistics Society,2010, pp. 175-186).

14. Kager, R., "Optimality Theory". United Kingdom: Cambridge University Press, 1999.

15. Campbell, L. \& Mixco, M. J. "A Glossary of Historical Linguistics". Edinburgh: Edinburgh University Press,2007, pp. 133-160.

16. Campbell, L. (1998). Historical Linguistics: An Introduction. Edinburgh: Edinburgh University Press,1998, pp.90-105.

17. Gussenhoven, C. \& Haikes. "Optimality Theory: Constraint Interaction in Generative",1998, pp.50-70.

\section{AUTHORS PROFILE}



\section{Dedy Suhery}

2015-2018 : S3 (PhD) Aligarh Muslim University, India. Linguistics Department. 2008-2011 : MA at Islamic University of Northy Sumatra Indonesia 2001 - 2006.Research works : (March 18-19,2017) on Language Attitude of Singkil Students in the Context of Bilingualism: A Study of Sociolinguistics. *National Conference on Teaching of English in Rural Areas and English as Medium of the Instruction organized by the Department of Education, NCERT, Delhi (March 2023,2017). * The 1st Annual International Conference on Language and Literature organized by Faculty of Literature, UISU Medan, Indonesia (April 18-19,2018) on Social Contexts of Phonological Contrasts and Indexicality: Variability and Identity among Singkils. www.knepublishing.com/index.php. A 3-day International Symposium on Linguistics across Discipline organized by the Department of Linguistics, A.M.U in collaboration with CIIL, Mysore and ICSSR, New Delhi ( 2nd4th November, 2018) on A Comparative Study of Experiential Function in English and Bahasa Indonesia. Learning Harmony Model through Multilingual and Multicultural Education in Islamic Boarding School (A Case study in Darul Arafah Raya, North Sumatra, Indonesia)/IJELLH (International Journal of English Language, Literature in Humanities) vol 7 No 2 (2019): ISSN 2321-7065. Phonological Property of Syllable Struture and Economy in Urdu: An OT Account (2019).

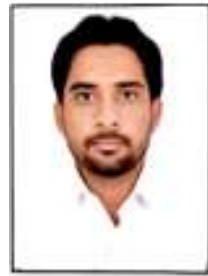

\section{Mohd Hamid Raza.}

Phd scholar at Department Linguistics of Aligarh Muslim University, India. Research work : Phonological Property of Syllable Struture and Economy in Urdu: An OT Account (2019).

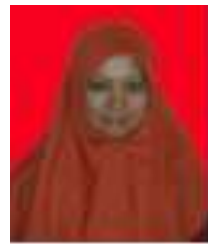

\section{Happy Sri Rezeki Purba}

(BA) Islamic University of North Sumatra 2005 MA Universitas Negeri Medan, Department Of Applied Linguistics, Medan ,Indonesia. (2010). Research works : 1 .The use of contextual teaching learning (CTL) method to improve students speaking mastery at the grade XI SMK Negeri 1 Padangsidimpuan (2016),Phonological Processes in Language Acquisition by Children of three Years Old (2016),3.Ethical Problems Related to Language Practice in Islamic Perspective (2017),Development of Teaching Material Vocabulary with the Mnemonic Keyword (2019),Phonological Property of Syllable Structure and Economy in Urdu: An OT Account (2019).

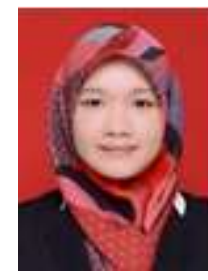

\section{Khairunnisah, M.Hum}

(BA) English Education of STKIP, TAPSEL Indonesia (2010), (MA) UNIMED Medan Indonesia Applied Linguistics (2016). Research works: The Influence of Listening to Song "Look at the Speaker" to Improve Student Speaking Ability at the Grade VIII in SMP N 4 Padangsidimpuan (2016), Analysis Experiential Function of Man and Woman in Writing Opinion (2018), Development of Teaching Material Vocabulary with the Mnemonic Keyword (2019). 